\title{
Climate reconstruction based on GDGT-based proxies in a paleosol sequence in Japan: Postdepositional effect on the estimation of air temperature
}

\author{
Yasuto Yamamoto $^{\mathrm{a}, 1}$, Taku Ajioka ${ }^{\mathrm{a}, 2}$, Masanobu Yamamoto ${ }^{\mathrm{a}, \mathrm{b}, *}$ \\ ${ }^{a}$ Graduate School of Environmental Science, Hokkaido University, Kita-10, Nishi-5, Kita-ku, Sapporo 060-0810, Japan \\ ${ }^{\mathrm{b}}$ Faculty of Environmental Earth Science, Hokkaido University, Kita-10, Nishi-5, Kita-ku, Sapporo 060-0810, Japan
}

\section{A R T I C L E I N F O}

\section{Article history:}

Available online 21 January 2015

\section{Keywords:}

GDGT

MBT/CBT

Paleotemperature

Japan

Holocene

\begin{abstract}
A B S T R A C T
We investigated branched and isoprenoid glycerol dialkyl glycerol tetraethers (GDGTs) in surface soils and a paleosol sequence to understand the effects of environmental and postdepositional factors on branched GDGT composition in different soil types and to reconstruct the past changes in the mean annual air temperature (MAAT) in southwestern Japan during the last $15 \mathrm{ka}$. The estimated MAAT was overestimated by $6{ }^{\circ} \mathrm{C}$ and $2{ }^{\circ} \mathrm{C}$ when the global and regional soil calibrations were applied, respectively. Additionally, the estimated MAAT increased downward by a maximum of $4{ }^{\circ} \mathrm{C}$ in the upper $30 \mathrm{~cm}$ of the soil sequence. This is likely to reflect the addition of newly produced branched GDGTs in subsurface soils. The estimated MAATs in a paleosol sequence are thus $\sim 10^{\circ} \mathrm{C}$ and $\sim 6^{\circ} \mathrm{C}$ higher than those expected when the global and regional soil calibrations were applied, respectively, but the variation agrees with the Holocene variation in the MAAT estimated by the pollen assemblage. This indicates that the MBT'/CBTderived MAAT is biased, but the variation reflects the past changes in MAAT.
\end{abstract}

(c) 2014 Elsevier Ltd and INQUA. All rights reserved.

\section{Introduction}

Branched glycerol dialkyl glycerol tetraethers (branched GDGTs) have been commonly found in peats, soils, and rivers, lake, and marine sediments (Schouten et al., 2000; Sinninghe Damsté et al., 2000; Hopmans et al., 2004; Schouten et al., 2013). They are thought to be the membrane lipids of Bacteria based on the stereochemistry of glycerol moiety (Weijers et al., 2006a, b). A branched GDGT was detected in an Acidobacterium (Sinninghe Damsté et al., 2011). Branched GDGTs in environmental samples consist of $C_{66}, C_{67}$, and $C_{68}$ homologs with 0-2 cyclopentane moieties (Weijers et al., 2006a). Weijers et al. (2007b) proposed a new paleotemperature index, the methylation index and the cyclization ratio of branched tetraethers (MBT/CBT), based on the empirical

\footnotetext{
* Corresponding author. Faculty of Environmental Earth Science, Hokkaido University, Kita-10, Nishi-5, Kita-ku, Sapporo 060-0810, Japan.

E-mail address: myama@ees.hokudai.ac.jp (M. Yamamoto).

1 Present address: Dainippon Toryo, Co. Ltd, 1-124, Nishikujo 6-chome, Konohana-ku, Osaka 554-0012 Japan.

2 Present address: National Institute of Advanced Industrial Science and Technology, Higashi 1-1-1, Tsukuba 305-8567 Japan.
}

correlation between the MBT/CBT values in soils and mean annual air temperatures (MAATs).

MBT/CBT has been applied in marine, lacustrine and terrestrial settings (e.g., Weijers et al., 2007a; Ajioka et al., 2014a). However, discrepancies between the expected paleoclimate conditions and proxy-derived results have often been observed. The discrepancy has been attributed to the seasonality of branched GDGT production (Peterse et al., 2011, 2012; Zech et al., 2012), the influence of precipitation (Weijers et al., 2007b; Peterse et al., 2012), the influence of coeluted GDGT isomers (Zech et al., 2012), the overprint of GDGT composition by the subsurface production of branched GDGTs (Zech et al., 2012; Ajioka et al., 2014a), redeposition of branched GDGTs (Zech et al., 2012) and the influence of plant root bacteria on soil GDGT composition (Huguet et al., 2013). These studies suggest that caution is necessary for the application of the $\mathrm{MBT} / \mathrm{CBT}$ index in terrestrial paleosols to paleotemperature estimates. Local and regional MBT/CBT calibrations can reduce the offsets between estimated and measured values (e.g., Peterse et al., 2012; Ajioka et al., 2014a) but constrain their applicability. It is necessary to understand more about the source and fate of branched GDGTs in soils as well as the environmental and ecological factors influencing GDGT distributions. 
Isoprenoid GDGTs have been found in marine sediments (e.g., Schouten et al., 2000) and soil (e.g., Weijers et al., 2006b) and are produced by Archaea (Nishihara et al., 1987). Based on their composition, the $\mathrm{TEX}_{86}$ paleothermometer and the methane index (MI) have been proposed as indices of paleotemperature and anaerobic methane oxidation activity, respectively (Schouten et al., 2002; Zhang et al., 2011). The branched and isoprenoid tetraether (BIT) index is used to estimate the contribution of terrestrial soil to marine sediments (Hopmans et al., 2004).

The climate of southwest and central Japan is sensitive to East Asian summer monsoon variability (Yoshino, 1965). Paleoclimate records from terrestrial archives are therefore useful to understand the past changes in the East Asian summer monsoon. The MBT'/CBT index was investigated in soils, river sediments, and lake surface sediments in the Lake Biwa drainage basin in central Japan (Ajioka et al., 2014a) and was applied to Lake Biwa sediments for the reconstruction of lake $\mathrm{pH}$ during the last $280 \mathrm{ka}$ (Ajioka et al., 2014b). Ajioka et al. (2014b) assumed that lake water $\mathrm{pH}$ reflected the summer air temperature via chemical weathering and the resultant eutrophication of lake water, but this assumption must be endorsed by other proxy records. The reconstruction of air temperature will help to better understand East Asian summer monsoon variability.

Here, we investigated branched GDGTs in surface soils and a paleosol sequence to understand the source and fate of GDGTs in different soil types and reconstruct the past changes in the MAAT in southwestern Japan. We established a regional MBT'/CBT-pH/temperature calibration based on data from the study area and the Lake Biwa drainage basin, and we also discuss the impacts of postdepositional effects on branched GDGT composition for better paleotemperature reconstruction.

\section{Samples and method}

\subsection{Soil samples}

Soil samples $(0-30 \mathrm{~cm}, 5-\mathrm{cm}$ interval) were collected from a total of 25 sites from the Ohno and Oita River basins in Oita Prefecture, Kyushu Island, in southwest Japan in December 2010 (Fig. 1). The altitude in this region ranges from $163 \mathrm{~m}$ to $1010 \mathrm{~m}$. The soil samples comprised 17 andosols (called Kuroboku in Japanese), four brown forest soils, and three calcareous soils (Table 1). Andosol
Table 1

List of surface soil samples.

\begin{tabular}{|c|c|c|c|c|}
\hline Site & Latitude & Longitude & Altitude (m) & Soil type \\
\hline 1 & $33^{\circ} 03^{\prime} 50.64^{\prime \prime} \mathrm{N}$ & $131^{\circ} 13^{\prime} 47.46^{\prime \prime} \mathrm{E}$ & 1010 & Andosol \\
\hline 2 & $33^{\circ} 03^{\prime} 46.56^{\prime \prime} \mathrm{N}$ & $131^{\circ} 13^{\prime} 42.00^{\prime \prime} \mathrm{E}$ & 1019 & Andosol \\
\hline 3 & $33^{\circ} 03^{\prime} 34.20^{\prime \prime} \mathrm{N}$ & $131^{\circ} 13^{\prime} 47.04^{\prime \prime} \mathrm{E}$ & 985 & Andosol \\
\hline 4 & $33^{\circ} 03^{\prime} 20.16^{\prime \prime} \mathrm{N}$ & $131^{\circ} 13^{\prime} 49.50^{\prime \prime} \mathrm{E}$ & 948 & Andosol \\
\hline 6 & $33^{\circ} 03^{\prime} 20.76^{\prime \prime} \mathrm{N}$ & $131^{\circ} 15^{\prime} 13.32^{\prime \prime} \mathrm{E}$ & 912 & Andosol \\
\hline 7 & $33^{\circ} 03^{\prime} 22.14^{\prime \prime} \mathrm{N}$ & $131^{\circ} 15^{\prime} 22.26^{\prime \prime} \mathrm{E}$ & 837 & Andosol \\
\hline 8 & $33^{\circ} 04^{\prime} 00.18^{\prime \prime} \mathrm{N}$ & $131^{\circ} 17^{\prime} 44.70^{\prime \prime} \mathrm{E}$ & 748 & Andosol \\
\hline 9 & $33^{\circ} 03^{\prime} 55.68^{\prime \prime} \mathrm{N}$ & $131^{\circ} 18^{\prime} 07.26^{\prime \prime} \mathrm{E}$ & 708 & Andosol \\
\hline 10 & $33^{\circ} 03^{\prime} 50.95^{\prime \prime} \mathrm{N}$ & $131^{\circ} 17^{\prime} 37.80^{\prime \prime} \mathrm{E}$ & 757 & Andosol \\
\hline 11 & $33^{\circ} 03^{\prime} 23.28^{\prime \prime} \mathrm{N}$ & $131^{\circ} 17^{\prime} 55.98^{\prime \prime} \mathrm{E}$ & 686 & Andosol \\
\hline 12 & $33^{\circ} 03^{\prime} 08.04^{\prime \prime} \mathrm{N}$ & $131^{\circ} 18^{\prime} 09.90^{\prime \prime} \mathrm{E}$ & 663 & Andosol \\
\hline 13 & $33^{\circ} 02^{\prime} 52.38^{\prime \prime} \mathrm{N}$ & $131^{\circ} 18^{\prime} 23.16^{\prime \prime} \mathrm{E}$ & 636 & Andosol \\
\hline 14 & $33^{\circ} 02^{\prime} 27.48^{\prime \prime} \mathrm{N}$ & $131^{\circ} 18^{\prime} 53.04^{\prime \prime} \mathrm{E}$ & 608 & Andosol \\
\hline 15 & $33^{\circ} 02^{\prime} 08.64^{\prime \prime} \mathrm{N}$ & $131^{\circ} 18^{\prime} 01.98^{\prime \prime} \mathrm{E}$ & 611 & Andosol \\
\hline 17 & $33^{\circ} 02^{\prime} 50.82^{\prime \prime} \mathrm{N}$ & $131^{\circ} 23^{\prime} 51.24^{\prime \prime} \mathrm{E}$ & 593 & Andosol \\
\hline 18 & $33^{\circ} 03^{\prime} 23.70^{\prime \prime} \mathrm{N}$ & $131^{\circ} 23^{\prime} 52.02^{\prime \prime} \mathrm{E}$ & 582 & Andosol \\
\hline 20 & $33^{\circ} 05^{\prime} 52.50^{\prime \prime} \mathrm{N}$ & $131^{\circ} 26^{\prime} 07.20^{\prime \prime} \mathrm{E}$ & 535 & Andosol \\
\hline 21 & $33^{\circ} 07^{\prime} 24.12^{\prime \prime} \mathrm{N}$ & $131^{\circ} 27^{\prime} 25.98^{\prime \prime} \mathrm{E}$ & 457 & Andosol \\
\hline 16 & $32^{\circ} 59^{\prime} 49.20^{\prime \prime} \mathrm{N}$ & $131^{\circ} 26^{\prime} 51.72^{\prime \prime} \mathrm{E}$ & 225 & Brown forest soil \\
\hline 22 & $33^{\circ} 03^{\prime} 32.52^{\prime \prime} \mathrm{N}$ & $131^{\circ} 30^{\prime} 17.28^{\prime \prime} \mathrm{E}$ & 341 & Brown forest soil \\
\hline 23 & $33^{\circ} 02^{\prime} 02.28^{\prime \prime} \mathrm{N}$ & $131^{\circ} 31^{\prime} 56.76^{\prime \prime} \mathrm{E}$ & 238 & Brown forest soil \\
\hline 24 & $33^{\circ} 00^{\prime} 32.04^{\prime \prime} \mathrm{N}$ & $131^{\circ} 33^{\prime} 00.24^{\prime \prime} \mathrm{E}$ & 264 & Brown forest soil \\
\hline 25 & $33^{\circ} 00^{\prime} 32.98^{\prime \prime} \mathrm{N}$ & $131^{\circ} 43^{\prime} 59.12^{\prime \prime} \mathrm{E}$ & 163 & Calcareous soil \\
\hline 26 & $33^{\circ} 00^{\prime} 40.44^{\prime \prime} \mathrm{N}$ & $131^{\circ} 44^{\prime} 05.46^{\prime \prime} \mathrm{E}$ & 182 & Calcareous soil \\
\hline 27 & $33^{\circ} 00^{\prime} 42.72^{\prime \prime} \mathrm{N}$ & $131^{\circ} 44^{\prime} 05.76^{\prime \prime} \mathrm{E}$ & 185 & Calcareous soil \\
\hline
\end{tabular}

is developed as a Holocene soil that is supposed to be formed by slash-and-burn farming (Yamanoi, 1996). The climatological mean annual air temperatures (MAATs) at sampling sites were estimated from their altitudes according to

MAAT $\left({ }^{\circ} \mathrm{C}\right)=15.9-0.0055 \times$ altitude $(\mathrm{m})\left(r^{2}=0.92\right)$.

This was obtained by regression of instrumental air temperatures in the period from 1981 to 2010 from 19 different meteorological stations in the study area (Supplementary Material Table 1; Data from the Japan Meteorological Agency; available at http:// www.jma.go.jp/jma/index.html).

\subsection{Outcrop samples}

A soil sequence was sampled from the outcrop at site 5 in Kuju, Taketa City, Oita Prefecture $\left(33^{\circ} 03^{\prime} 21.59^{\prime \prime} \mathrm{N}, 131^{\circ} 15^{\prime} 36.53^{\prime \prime} \mathrm{E}, 830 \mathrm{~m}\right.$
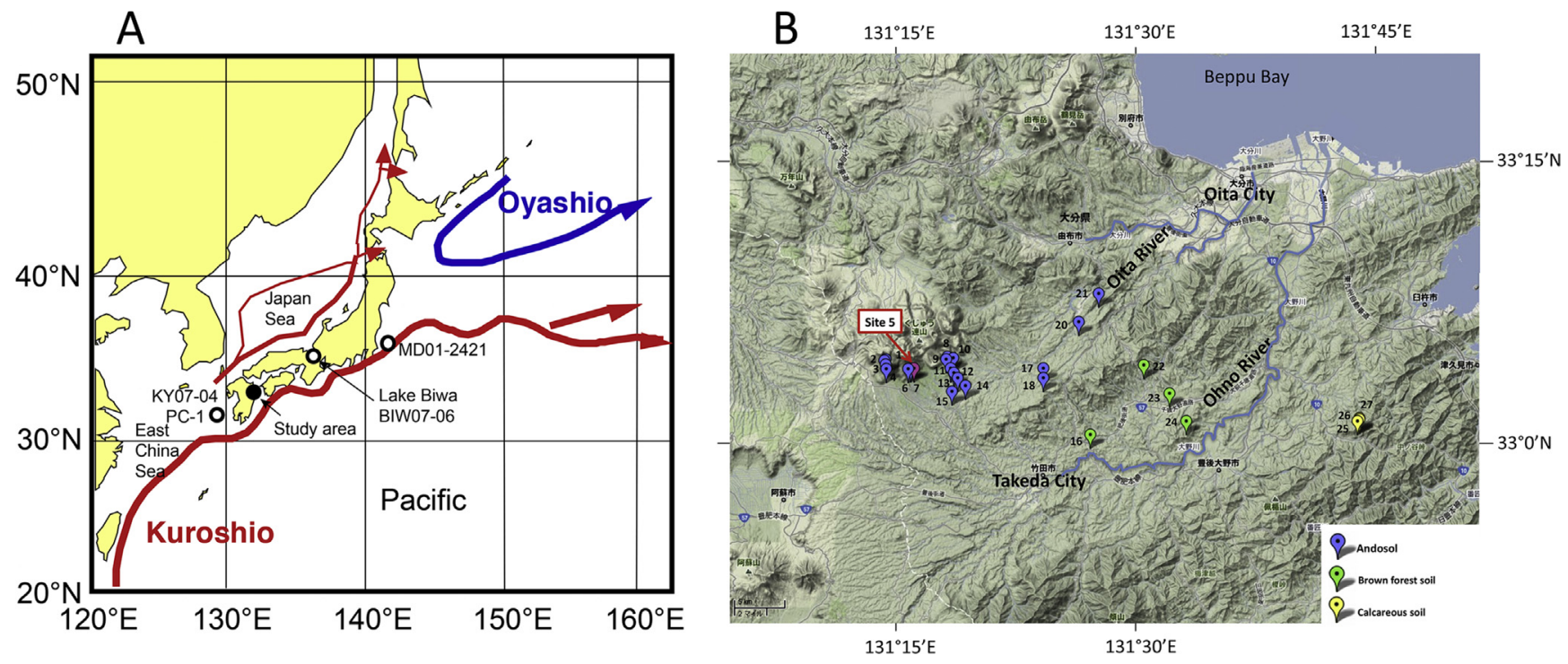

Fig. 1. Map showing (A) the locations of the study site and the other reference sites and (B) soil samples. 
altitude) in December 2010. The climatological MAAT at the site is $11.3^{\circ} \mathrm{C}$. A total of 27 samples ( $11 \mathrm{~cm}$ interval) were sampled from the 291-cm-long sequence (Fig. 2). The sediments consisted of loam in the lower horizon and andosol and volcanic ashes in the middle and upper horizons. At a nearby outcrop, volcanic ashes were described and the radiocarbon dates just above and below the ashes were determined by Kamata and Kobayashi (1997). The radiocarbon dates were converted to calendar ages by Intcal09 (Calib Rev 6.1.0) in this study (Table 2). The mean value of soil age above and below the ash was regarded as the age of the ash (Table 3). The lithological boundary between loam and andosol was dated at a nearby location by Okuno et al. (2004), and the radiocarbon dates were converted to calendar ages by Intcal09 (Calib Rev 6.1.0) in this study (Table 2). The age-depth model at site 5 was then created by the ages of volcanic ashes and the lithological boundary between loam and andosol (Table 3 ).

\subsection{Climate of the study area}

There are two meteorological stations at Taketa (261 $\mathrm{m}$ altitude, $\left.32^{\circ} 58.4^{\prime} \mathrm{N}, 131^{\circ} 23.9^{\prime} \mathrm{E}\right)$ and Inukai ( $100 \mathrm{~m}$ altitude, $33^{\circ} 03.9^{\prime} \mathrm{N}$, $131^{\circ} 37.9^{\prime} \mathrm{E}$ ), where the MAATs were $14.5^{\circ} \mathrm{C}$ and $15.0^{\circ} \mathrm{C}$, and the mean annual precipitation values were $1826 \mathrm{~mm}$ and $1726 \mathrm{~mm}$, respectively, in the period from 1981 to 2010 (Data from the Japan Meteorological Agency; available at http://www.jma.go.jp/jma/ index.html). The climate of the study area is governed by the East Asian monsoon. The summer monsoon brings warm and humid conditions, whereas the winter monsoon brings cold and dry conditions (Fig. 3).

\subsection{Analytical methods}

\subsubsection{Lipid extraction and separation}

Soil samples were freeze-dried and dry sieved to remove pebbles, roots and plant debris. Lipids were extracted $(\times 3)$ from 1 to
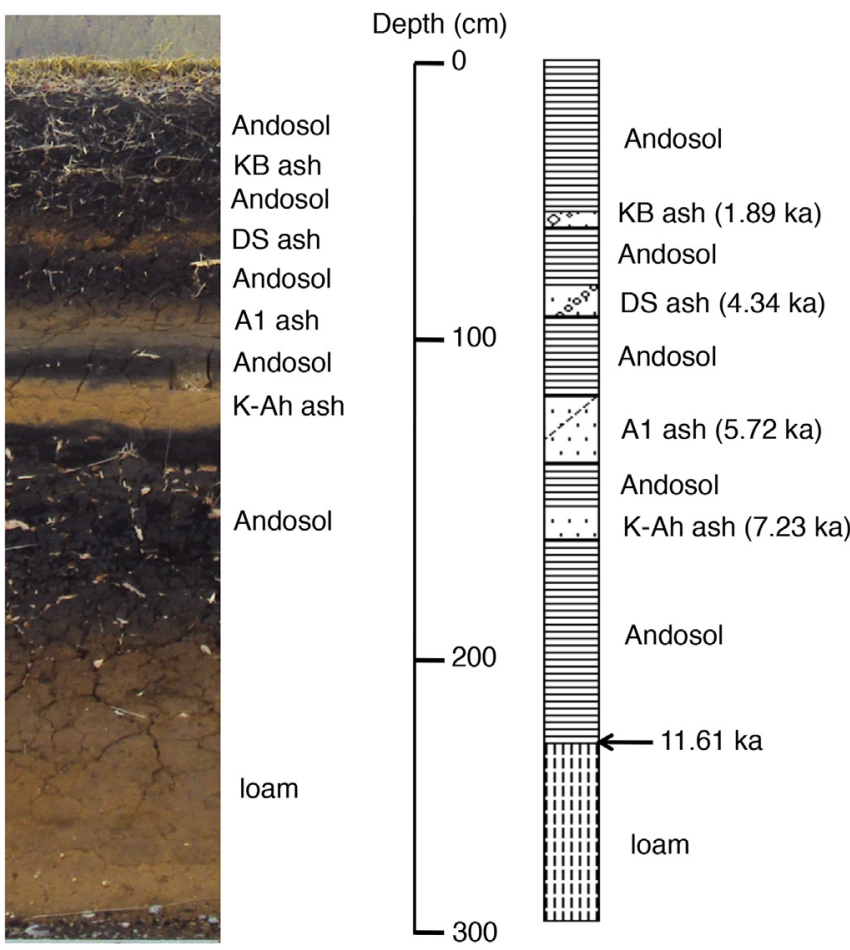

Fig. 2. Photograph and lithologic column of the paleosol sequence.
Table 2

Ages of soils and an ash in references.

\begin{tabular}{lccc}
\hline Stratigraphic position & \multicolumn{2}{c}{ Conventional age (BP) } & Calendar age (cal) \\
\hline Just above KB ash & $1710 \pm 50$ & 1672 & 1 \\
Just below KB ash & $2150 \pm 80$ & 2111 & 1 \\
Just above DS ash & $3570 \pm 110$ & 3843 & 1 \\
Just below DS ash & $4300 \pm 270$ & 4829 & 1 \\
Just above A1 ash & $4620 \pm 110$ & 5374 & 1 \\
Just below A1 ash & $5280 \pm 140$ & 6064 & 1 \\
K-Ah ash & $6280 \pm 130$ & 7232 & 1 \\
Andosol just above the & $10,080 \pm 130$ & 11,611 & 2 \\
\multicolumn{2}{c}{ Andosol-loam boundary } & & \\
\hline
\end{tabular}

1: Kamata and Kobayashi (1997), 2: Okuno et al. (2004).

Table 3

Ages of ashes and lithological boundary at site 5 .

\begin{tabular}{llc}
\hline Depth $(\mathrm{cm})$ & Name of layer & Calendar age (cal) \\
\hline $52-57$ & KB ash & 1891 \\
$76-87$ & DS ash & 4336 \\
$114-136$ & A1 ash & 5719 \\
$151-162$ & K-Ah ash & 7232 \\
232 & Andosol-loam boundary & 11,611 \\
\hline
\end{tabular}

$5 \mathrm{~g}$ of dried soil using a DIONEX Accelerated Solvent Extractor ASE200 at $100{ }^{\circ} \mathrm{C}$ and 1000 psi for 10 min with $11 \mathrm{ml}$ of $\mathrm{CH}_{2} \mathrm{Cl}_{2}-\mathrm{CH}_{3} \mathrm{OH}$ (6:4) and then concentrated. The lipid extract was separated into four fractions using column chromatography $\left(\mathrm{SiO}_{2}\right.$ with $5 \%$ distilled water; i.d., $5.5 \mathrm{~mm}$; length, $45 \mathrm{~mm}$ ): F1 (saturated hydrocarbons), $3 \mathrm{ml}$ hexane; F2 (aromatic hydrocarbons), $3 \mathrm{ml}$ hexane-toluene (3:1); F3 (ketones), $4 \mathrm{ml}$ toluene; F4 (polar compounds), $3 \mathrm{ml}$ toluene- $\mathrm{CH}_{3} \mathrm{OH}(3: 1)$.

\subsubsection{GDGT analysis}

An aliquot of F4 was dissolved in hexane-2-propanol (99:1) and filtered and analyzed using high performance liquid chromatography-mass spectrometry (HPLC-MS) with an Agilent 1100 HPLC or Shimadu SIL-20AD system connected to a Bruker Daltonics micrOTOF-HS time-of-flight mass spectrometer. Separation was conducted using a Prevail Cyano column $(2.1 \times 150 \mathrm{~mm}, 3 \mu \mathrm{m}$; Alltech) and maintained at $30^{\circ} \mathrm{C}$ following the method of Hopmans et al. (2000) and Schouten et al. (2007). Conditions were: flow rate $0.2 \mathrm{ml} / \mathrm{min}$, isocratic with 99\% hexane and 1\% 2-propanol for the first 5 min followed by a linear gradient to 1.8\% 2-propanol over $45 \mathrm{~min}$. Detection was achieved using atmospheric pressure, positive ion chemical ionization-mass spectrometry (APCI-MS). The spectrometer was run in full scan mode (m/z 500-1500). Compounds were identified by comparing mass spectra and retention times with those of GDGT standards (formed from the main phospholipids of Thermoplasma acidophilum via acid hydrolysis) and those in the literature (Hopmans et al., 2000). Quantification was achieved by integrating the summed peak areas in the $(\mathrm{M}+\mathrm{H})^{+}$and the isotopic $(\mathrm{M}+\mathrm{H}+1)^{+}$chromatograms and comparing these with the peak area of an internal standard $\left(\mathrm{C}_{46}\right.$ GTGT; Patwardhan and Thompson, 1999) in the $(\mathrm{M}+\mathrm{H})^{+}$chromatogram, according to the method of Huguet et al. (2006). The correction values of ionization efficiency between isoprenoid and branched GDGTs and the internal standard was obtained by comparing the peak areas of $T$. acidophilum-derived mixed GDGTs and $\mathrm{C}_{46}$ GTGT in known amounts (Yamamoto and Polyak, 2009) and isolated isoprenoid and branched GDGTs (Schouten et al., 2014). In routine analysis, the working standard that is a mixture of $\mathrm{C}_{46}$ GTGT and the purified GDGTs from an East China Sea sediment was inserted every 20 samples to monitor changes in the ionization efficiency. The standard deviation of a 


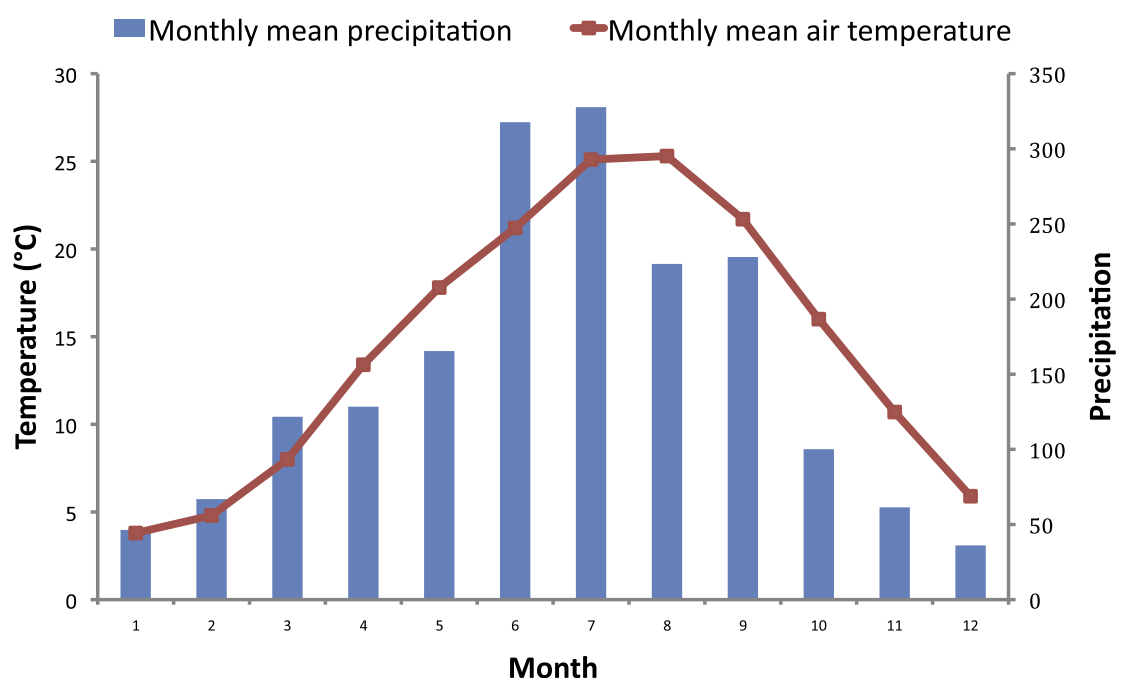

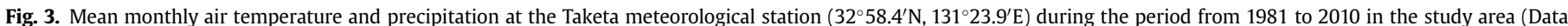
from the Japan Meteorological Agency; available at http://www.jma.go.jp/jma/index.html).

replicate analysis was $3.0 \%$ of the concentration for each compound.

Branched and isoprenoid tetraether (BIT) index was calculated from the concentrations of GDGT I (I), GDGT II (II), GDGT III (III) and crenarchaeol using the following expression (Hopmans et al., 2004):

$\mathrm{BIT}=([\mathrm{I}]+[\mathrm{II}]+[\mathrm{III}]) /([\mathrm{I}]+[\mathrm{II}]+[\mathrm{III}]+[$ crenarchaeol $])$.

The standard deviations of replicate analyses averaged 0.004 in this study.

The cyclization ratio of branched tetraethers (CBT) and the methylation index of branched tetraethers (MBT') were calculated as (Weijers et al., 2007b; Peterse et al., 2012):

$\mathrm{CBT}=-\log ([\mathrm{Ib}]+[\mathrm{IIb}]) /([\mathrm{I}]+[\mathrm{II}])$,

$\mathrm{MBT}^{\prime}=([\mathrm{I}]+[\mathrm{Ib}]+[\mathrm{Ic}]) /([\mathrm{I}]+[\mathrm{Ib}]+[\mathrm{Ic}]+[\mathrm{II}]+[\mathrm{IIb}]+[\mathrm{IIC}]+[\mathrm{III}])$.

The standard deviations of replicate analyses of CBT and MBT' averaged 0.085 and 0.008 , respectively, in this study.

The methane index (MI) was calculated as per Zhang et al. (2011):

$\mathrm{MI}=([$ GDGT-1] $+[$ GDGT-2] $+[$ GDGT-3])/([GDGT-1] + [GDGT-

$2]+[$ GDGT-3] + [crenarchaeol $]+[$ crenarchaeol regioisomer $])$

The standard deviations of replicate analyses averaged 0.03 in this study.

\section{5. pH measurement}

Soil sample ( $4 \mathrm{~g}$ ) was soaked with $10 \mathrm{ml}$ distilled water, mixed well and kept for $2 \mathrm{~h}$. The soil-water mixture was mixed again and $\mathrm{pH}$ was measured with a $\mathrm{pH}$ meter (pH BOY-P2, Shindengen Electronic Mfg. Co., LTD, Japan).

\section{Results}

\subsection{Surface soils}

\subsubsection{Spatial variation in surface soils}

Surface soils $(0-5 \mathrm{~cm})$ were investigated at 25 different sites of the Ohno and Oita River basins (Appendix II). The CBT was negatively correlated with soil $\mathrm{pH}\left(r^{2}=0.61\right.$; Fig. $\left.4 \mathrm{~A}\right)$. No different trend was observed in different soil types such as andosols, brown forest soils, and calcareous soils (Fig. 4A). Because the range of MAATs was too small to investigate the relationship between CBT/ MBT and MAAT in the samples from the Ono and Oita River basins, we investigated their relationship in the datasets from both the Ohno and Oita River basins and from the Lake Biwa drainage basin (Ajioka et al., 2014a). The MBT' was correlated with CBT and MAAT in the samples $\left(r^{2}=0.51\right.$; Fig. $\left.4 \mathrm{~B}\right)$. The obtained regression equations (called "regional calibration" hereafter) are shown in Table 4, along with those obtained from global soil (Peterse et al., 2012, called "global calibration" hereafter) and Lake Biwa soil (Ajioka et al., 2014a) datasets. Some of the estimated soil $\mathrm{pH}$ values in this study fell outside the root mean square error ( 0.8 unit) of the CBT-pH calibration of the global soil set (Peterse et al., 2012; Fig. 4C). The deviations between measured and estimated soil $\mathrm{pH}$ values were $1.0 \pm 0.5$ and $0.5 \pm 0.6$, when the global and regional calibrations were applied, respectively.

The estimated MAATs based on the global calibration were higher than the climatological MAAT (Fig. 4D). About half of the estimated MAATs in this study fell within the root mean square error $\left(5^{\circ} \mathrm{C}\right)$ of the global calibration (Peterse et al., 2012). MAATs based on the regional calibration also tended to be higher than the climatological MAAT, but most samples were within the errors of calibration (Fig. 4D). The deviations between climatological and estimated MAATs were $6.1 \pm 2.0 \mathrm{C}^{\circ}$ and $1.8 \pm 2.1 \mathrm{C}^{\circ}$ when the global and regional calibrations were applied, respectively.

\subsubsection{Depth variation}

Depth variations in GDGTs were examined at four different sites (Appendix III); andosol at site 2 (1019 $\mathrm{m} \mathrm{high),} \mathrm{andosol} \mathrm{at} \mathrm{site} 20$ (535 m), brown forest soil at site $22(341 \mathrm{~m})$, and calcareous soil at site 25 (163 m; Table 1). At sites 20 and 25, both branched and isoprenoid GDGT concentrations showed a decreasing trend with depth (Fig. 5). CBT did not change significantly because measured soil pH was nearly constant, but MBT' showed an increasing trend with depth by reflecting the decrease in the relative abundance of compound II compared with compounds I and Ib (Fig. 5). At site 2 , branched and isoprenoid GDGT concentrations were maximal at a depth of $10-15 \mathrm{~cm}$, whereas at site 22 , branched and isoprenoid GDGT concentrations showed an increasing trend with depth (Fig. 5). At both sites, CBT showed an decreasing trend with depth as the measured $\mathrm{pH}$ increased, whereas MBT' did not display an 

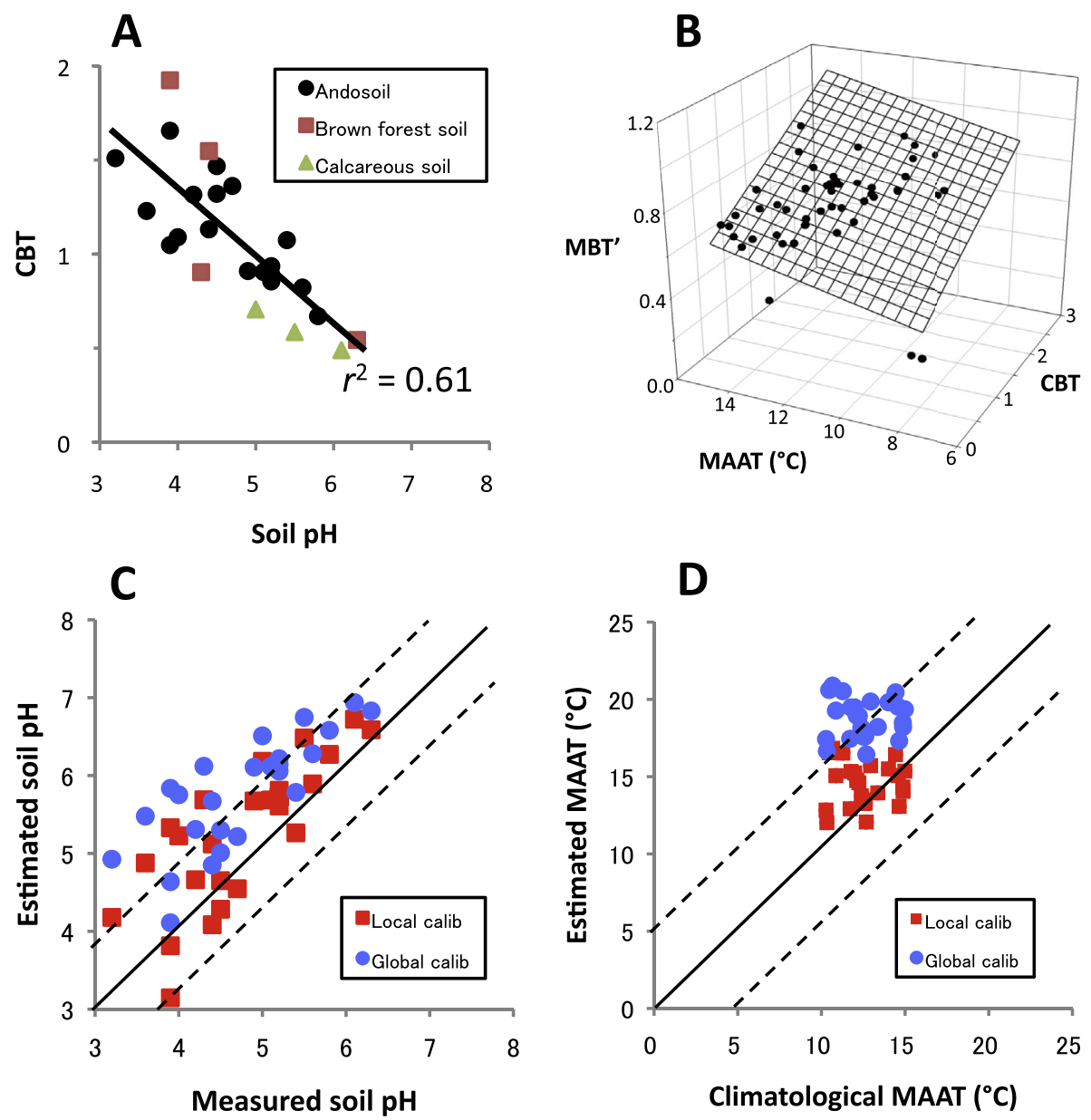

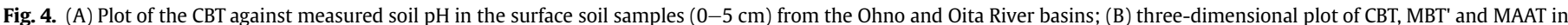

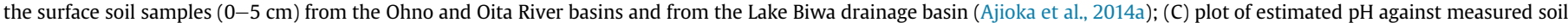

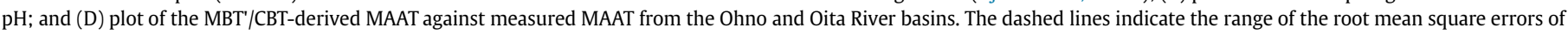
the CBT-pH and MBT'/CBT-MAAT calibrations (0.8 unit and $5{ }^{\circ} \mathrm{C}$, respectively) of the global soil set (Peterse et al., 2012).

increasing trend (Fig. 5). At all sites, BIT was consistently higher than 0.94, and MI increased with depth (Fig. 5).

\subsection{The Holocene sequence at the Kuju outcrop}

At the paleosol sequence of site 5 , the measured $\mathrm{pH}$ ranged from 5.6 to 5.8 , from 4.8 to 5.7 , and from 4.8 to 5.7 in glacial loam, andosol and volcanic ash layers, respectively (Appendix IV). Both branched and isoprenoid GDGT concentrations increased from glacial loam to Holocene andosol horizons (Fig. 6A). Concentrations were lower in volcanic ash layers than in andosols in the Holocene

Table 4

Relationships between $\mathrm{CBT} / \mathrm{MBT}$ ' and soil pH/MAAT in global, Lake Biwa drainage basin and Ohno-Oita River basin surface soil datasets.

\begin{tabular}{lllll}
\hline Name & Regression equation & $r^{2}$ & $\mathrm{n}$ & Reference \\
\hline Global soils & $\mathrm{pH}=7.90-1.97 \mathrm{CBT}$ & 0.70 & 176 & Peterse et al. (2012). \\
& MAAT $=0.81-5.67$ & 0.59 & 176 & \\
& CBT $+31.0 \mathrm{MBT}^{\prime}$ & & & \\
Biwa surface soils & $\mathrm{pH}=7.90-2.08 \mathrm{CBT}$ & 0.69 & 25 & Ajioka et al. (2014a). \\
$\quad(0-5 \mathrm{~cm})$ & $\mathrm{MAAT}=1.28-5.77$ & 0.68 & 25 & \\
& $\mathrm{CBT}+26.4 \mathrm{MBT}$ & & & \\
Biwa and Ohno-Oita & $\mathrm{pH}=7.94-2.49 \mathrm{CBT}$ & 0.54 & 50 & This study \\
$\begin{array}{l}\text { surface soils } \\
(0-5 \mathrm{~cm})\end{array}$ & $\mathrm{MAAT}=4.97-6.60$ & 0.51 & 50 & (Regional calibration) \\
& $\mathrm{CBT}+34.2 \mathrm{MBT}^{\prime}$ & & & \\
\hline
\end{tabular}

intervals (Fig. 6A). The estimated soil $\mathrm{pH}$ values were higher than the measured ones in the upper horizons but were lower in the lower horizons (Fig. 6B). On a $10-\mathrm{cm}$ scale, the soil $\mathrm{pH}$ estimated from CBT varied in response to measured soil pH (Fig. 6B). MBT' varied between 0.83 and 0.92 and increased downward, reaching a maximum at $\sim 150 \mathrm{~cm}$ and decreasing below (Fig. 6C).

\section{Discussion}

\subsection{Deviations in CBT-based $\mathrm{pH}$ and $M B T^{\prime} / C B T$-based MAAT from measured ones}

In the study samples, the CBT-based $\mathrm{pH}$ value and the MBT'/CBTbased MAAT were higher than the measured soil $\mathrm{pH}$ and MAAT values when applying global calibration (Fig. 4C and D). This tendency was also observed in the soils from the Lake Biwa drainage basin (Ajioka et al., 2014a). Chinese paleosol samples also showed the same tendency even when applying a new MBT'/CBT calibration (Peterse et al., 2012). This was interpreted as due to the fact that the estimated temperature reflected the summer temperature (Peterse et al., 2011). All of these samples derived from the East Asian monsoon region. The region is characterized by large seasonal variations in air temperature and precipitation (Wang et al., 2003). Because precipitation is much higher in summer than in winter (Wang et al., 2003), soil bacteria presumably grow prolifically in 

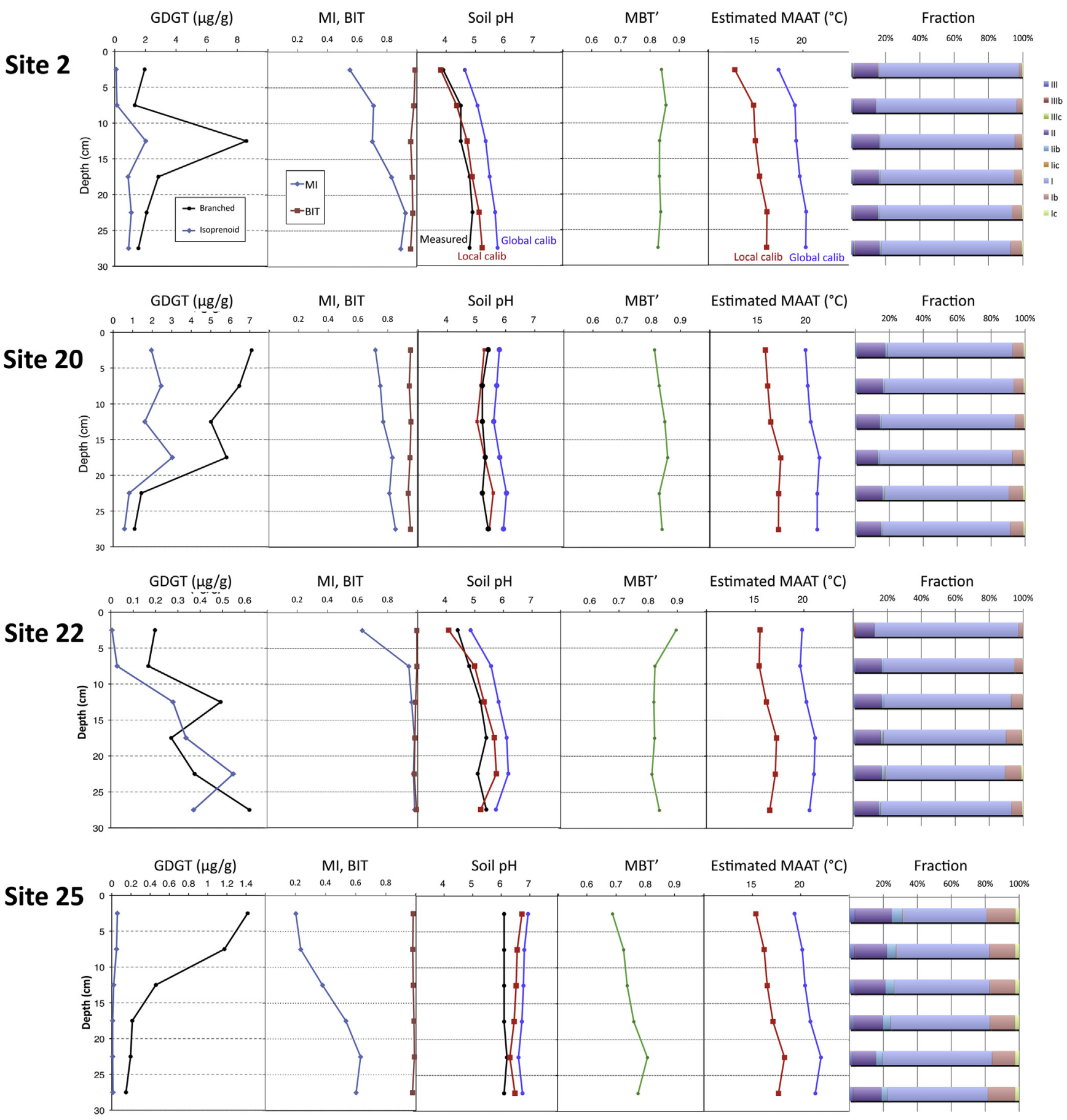

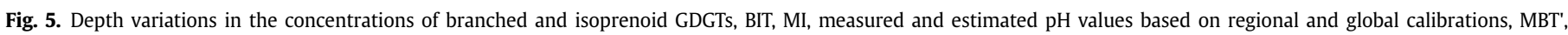

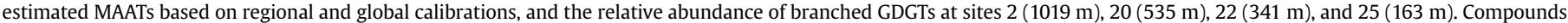
I-IIIb are listed in the Appendix.

warmer seasons. This is likely the reason that $\mathrm{MBT}^{\prime} / \mathrm{CBT}$ indices in the soils from the East Asian monsoon region considerably deviate from the global soil trend.

In this study, three different soil types showed no significant difference in the CBT and $\mathrm{pH}$ relationship (Fig. 4A). The difference among these three soil types originated from differences in their original rock types and the mechanisms of formation rather than a difference in the climate. In particular, andosol is an artificial soil that was formed by slash-and-burn farming (Yamanoi, 1996). The CBT trend in andosol was not different from those in brown forest and calcareous soils, suggesting that slash-and-burn farming is not a factor influencing CBT. This also suggests the soil types under the same climate conditions do not affect the results of MBT' and CBT results.

\subsection{Changes in GDGT composition near surface soils}

The MBT'/CBT-derived MAAT increased by a maximum of $4{ }^{\circ} \mathrm{C}$ in the upper $30 \mathrm{~cm}$ (Fig. 5). Recently, Huguet et al. (2013) reported that tree roots contain the branched GDGTs that have different CBT/ 


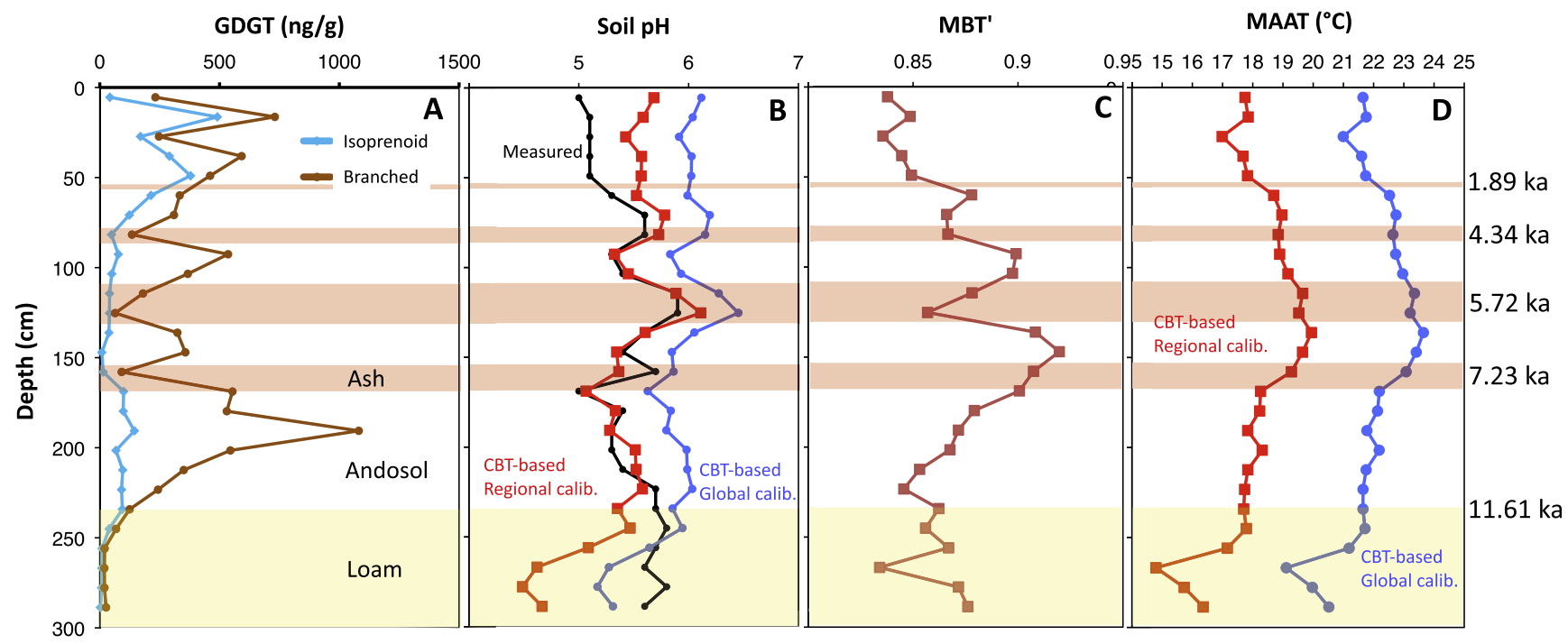

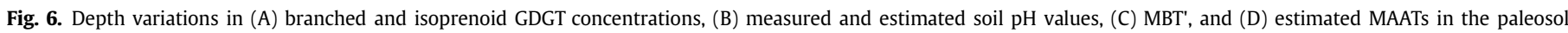
sequence based on regional and global calibrations in the paleosol sequence at site $5(830 \mathrm{~m})$.

MBT' values from those of the surrounding soils. The soil samples were sieved with a screen to remove the roots in this study. It is thus less likely that the GDGTs in roots affected changes in CBT/ MBT' in the study soil sequence.

At sites 20 and 25, the downward increase in MBT' (increase in compound I and decrease in compound II) shown in Fig. 5 is likely to reflect either the addition of freshly produced branched GDGTs or the degradation of branched GDGTs in subsurface soils. The same phenomenon was observed in subsurface soil sequences from Mt. Kilimanjaro (Zech et al., 2012) and the Lake Biwa estuary (Ajioka et al., 2014a). Because the pH did not substantially change with depth at these sites (Fig. 5), and temperature should be constant within the top $30 \mathrm{~cm}$, factors other than soil $\mathrm{pH}$ and temperature should change the branched GDGT composition. Free oxygen generally decreases with depth in the soil sequence. This change in the microenvironment results in a gradient of microbial communities, producing branched GDGTs of different composition. As a result, the MBT' and $\mathrm{CBT}$ are altered during the burial process, and the estimated $\mathrm{pH}$ and MAAT are biased.

At sites 2 and 22, the increase in CBT with depth resulted in the downward increase in the estimated MAAT (Fig. 5). The increase in branched GDGT concentration suggests that the addition of the freshly produced branched GDGTs would lower CBT in response to an elevation of soil $\mathrm{pH}$. Although it is not clear whether this process is the same as that which occurred at sites 20 and 25, postdepositional processes increased the estimated MAAT in the upper part of the soil sequence.

At all sites, BIT was constantly higher than 0.94, and MI increased with depth (Fig. 5). The high BIT is consistent with previous observations in soils (Hopmans et al., 2004; Schouten et al., 2013). The downward increase in MI is consistent with Ajioka et al. (2014a), who observed that crenarchaeol concentrations peaked at a shallower depth than GDGT-0 to -3 , suggesting the presence of a common microbial community in subsurface soil.

\subsection{Air temperature changes since $15 \mathrm{ka}$}

The MBT'/CBT-derived MAAT ranged from 19 to $24^{\circ} \mathrm{C}$ and from $15{ }^{\circ} \mathrm{C}$ to $20{ }^{\circ} \mathrm{C}$ when the global and regional calibrations were applied, respectively (Fig. 6). The uppermost sample showed $22{ }^{\circ} \mathrm{C}$ (by global calibration) and $18{ }^{\circ} \mathrm{C}$ (by regional calibration) (Fig. 6), $11^{\circ} \mathrm{C}$ and $7{ }^{\circ} \mathrm{C}$ higher than the MAAT $\left(11^{\circ} \mathrm{C}\right)$ in the study area, respectively. In the surface soils in the study area, the estimated MAATs based on global and regional calibrations were $\sim 6^{\circ} \mathrm{C}$ and $\sim 2{ }^{\circ} \mathrm{C}$ higher than the measured MAAT, respectively (Fig. 4D). Additionally, as discussed in the previous section, the estimated MAAT increased by a maximum of $4{ }^{\circ} \mathrm{C}$ in the uppermost layer of the soil sequence (Fig. 5). The upper surface of the study outcrop is used as a grass farm and the most recent soil was presumably removed by scraping. We assume that the estimated MAATs were modified toward higher values by a postdepositional microbial process. Peterse et al. (2011) reported the MBT'/CBT-derived MAAT was $9{ }^{\circ} \mathrm{C}$ higher than the measured MAAT in a Chinese loess sequence, which was interpreted to reflect the summer air temperature. Our results suggest that the postdepositional microbial process is an additional potential factor enhancing the estimated MAAT.

The estimated MAAT was $\sim 22{ }^{\circ} \mathrm{C}$ (by global calibration) and $\sim 18{ }^{\circ} \mathrm{C}$ (by regional calibration) in the early Holocene. It reached a maximum of $\sim 24{ }^{\circ} \mathrm{C}$ and $\sim 20{ }^{\circ} \mathrm{C}$ in the middle Holocene, and deceased to $\sim 21^{\circ} \mathrm{C}$ and $\sim 17{ }^{\circ} \mathrm{C}$, respectively, in the late Holocene (Fig. 6D). This variation agrees with Holocene variation in the MAAT estimated by a pollen assemblage in the Fukuoka Plain, northern Kyushu Island, $120 \mathrm{~km}$ northwest of the study site (Kuroda and Hatanaka, 1979), and at Mt. Yufu, $50 \mathrm{~km}$ northwest of the study site (Watanabe and Takahara, this volume). At the Fukuoka site, the pollen assemblage indicated that the MAAT was $1-2{ }^{\circ} \mathrm{C}$ higher in the middle Holocene than in the early and late Holocene (Kuroda and Hatanaka, 1979). At the Mt. Yufu site, dominant grass pollen changed from cool-temperate to warm-temperate species at $7.3 \mathrm{ka}$ (Wanatabe and Takahara, this volume), which corresponded to $\sim 1.2 \mathrm{C}^{\circ}$ rise around $7 \mathrm{ka}$ in our MAAT record. These correspondences with other climate records near the study site suggest that the MBT'/CBT-derived MAAT is biased, but the variation should reflect the past changes in MAAT. If the effect of postdepostional processes on the estimated MAAT were constant, the MBT'/CBT index is useful for estimating past changes in the MAAT.

The variation in the estimated MAAT at the study site agreed with variation in the CBT-based $\mathrm{pH}$ of Lake Biwa water in core BIW07-06 (Ajioka et al., 2014a, b) during the last $15 \mathrm{ka}$ (Fig. 7A). Ajioka et al. (2014b) assumed that the pH of Lake Biwa water reflected the summer temperature in central Japan. The variation in 

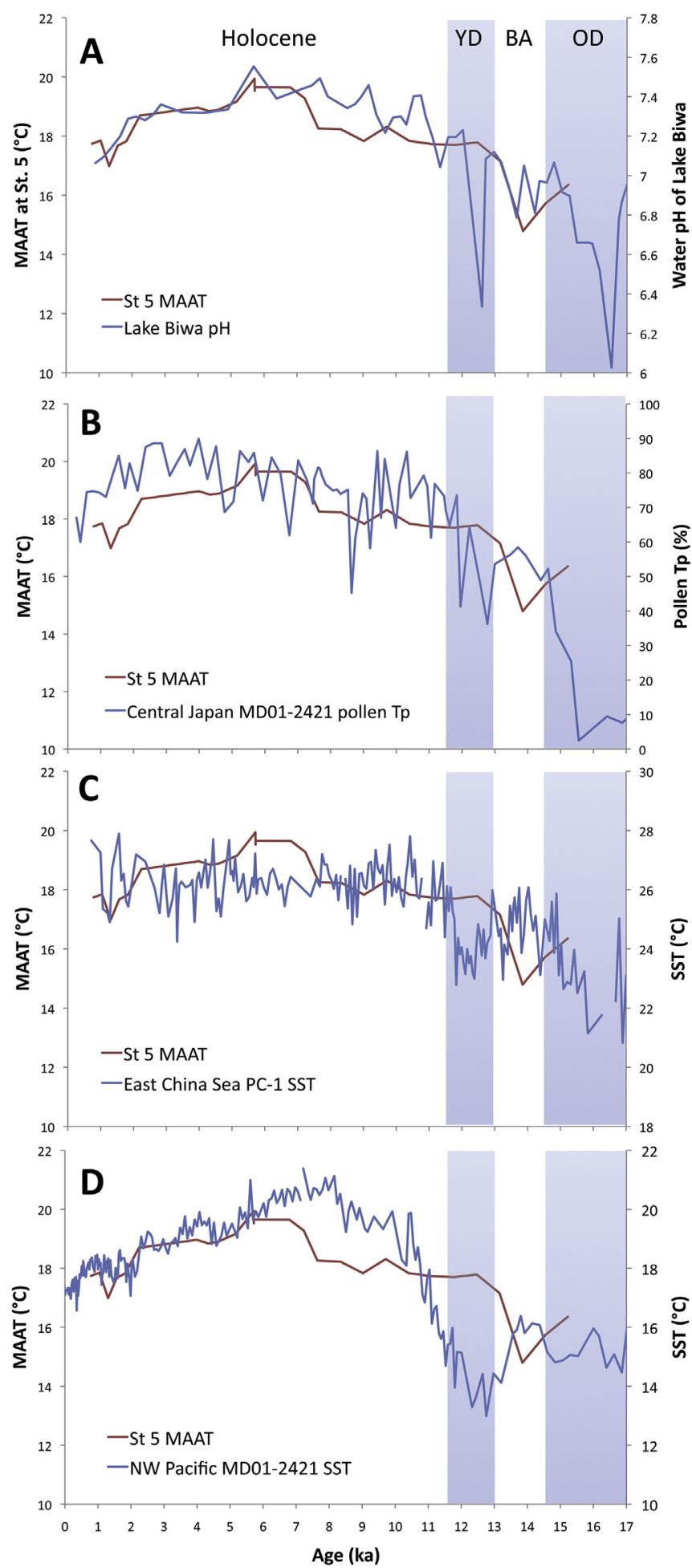

Fig. 7. The $\mathrm{MBT}^{\prime} / \mathrm{CBT}$-derived MAAT by regional calibration at site 5 with $(\mathrm{A})$ the CBTderived pH of Lake Biwa water in core BIW07-06 (Ajioka et al., 2014b), (B) the pollen Tp index in core MD01-2421 from the northwestern Pacific (Igarashi and Oba, 2006), (C) $\mathrm{Mg} / \mathrm{Ca}$-derived SST in core KY07-04 PC-1 (Kubota et al., 2010), and (D) $\mathrm{U}^{\mathrm{K} /}{ }_{37}$-derived SST in core MD01-2421 (Yamamoto et al., 2005; Isono et al., 2009) during the last $17 \mathrm{ka}$.

estimated MAAT is also consistent with the pollen temperature index $\mathrm{Tp}$ in the marine core MD01-2421 from the northwestern Pacific off central Japan (Fig. 7B; Igarashi and Oba, 2006). The correspondence between these records suggests that the maximum summer temperature occurred around 7-5 ka, which was likely due to an intensified summer monsoon.

However, the estimated MAAT at the study site was less consistent with the summer sea surface temperature (SST) records near the Japanese Islands (Yamamoto et al., 2005; Isono et al., 2009; Yamamoto, 2009; Kubota et al., 2010). The foramineral $\mathrm{Mg} / \mathrm{Ca}$ record in core KY07-04 PC1 from the northern East China Sea off Kyushu Island indicated that the summer sea surface temperature was $\sim 3{ }^{\circ} \mathrm{C}$ lower during the Younger Dryas period $(\sim 12 \mathrm{ka})$ and the end of the Oldest Dryas period ( 15 ka) (Fig. 7C; Kubota et al., 2010). The estimated MAAT at the study site was $\sim 19{ }^{\circ} \mathrm{C}$ at $\sim 14 \mathrm{ka}$ and $\sim 3{ }^{\circ} \mathrm{C}$ lower than in the late Holocene (Fig. 7C). Because the ages of soils were extrapolated before $11.6 \mathrm{ka}$, the precise correlation of events between our data and East China Sea records is difficult. The PC- 1 record did not show a significant middle Holocene warm period (Fig. 7C; Kubota et al., 2010), which is not consistent with the MAAT record at the study site. This mismatch was probably because the summer SST in the northern East China Sea was affected by complex factors such as the Kuroshio strength and Yantze River discharge rather than the summer air temperature (Kubota et al., 2010). Similarly, the $\mathrm{U}^{\mathrm{K}^{\prime}}{ }_{37}$-based summer SST record from core MD01-2421 from the northwestern Pacific off central Japan showed a cool climate during the Younger and Oldest Dryas periods and a warm climate around 7 ka (Fig. 7D; Yamamoto et al., 2005; Isono et al., 2009). The timing of warm periods was earlier in the SST record than in the MAAT record (Fig. 7D). Because the SST at the MD01-2421 site was sensitive to the latitudinal shift of the Kuroshio-Oyashio boundary and the North Pacific subtropical gyre circulation (Yamamoto, 2009), this time lag suggests that the variability in the subtropical gyre preceded the East Asian summer monsoon variability on a millennial timescale.

\section{Conclusions}

Analysis of soil sequences demonstrated the following phenomena: 1) The estimated soil $\mathrm{pH}$ and MAAT were overestimated when global calibration was applied. 2) The estimated MAAT increased by a maximum of $4{ }^{\circ} \mathrm{C}$ in the upper $30 \mathrm{~cm}$ of the soil sequence. 3) The downward increase in MBT' is likely to reflect the addition of newly produced branched GDGTs in subsurface soils. Postdepositional microbial processes are a potential factor enhancing the estimated MAAT. 4) The estimated MAAT agrees with Holocene variation in the MAAT estimated by the pollen assemblage. This suggests that the $\mathrm{MBT}^{\prime} / \mathrm{CBT}$-derived MAAT is biased, but the variation reflects the past changes in MAAT.

\section{Acknowledgements}

We thank Keiji Takemura (Kyoto University), Keiko Ohnishi, Tomohisa Irino, Masahito Abe, Tatsufumi Okino, and Masao Minagawa (Hokkaido University) for help with sampling, analysis and discussion. Constructive comments by two anonymous reviewers improved much this manuscript. The study is supported by grantsin-aid for Mitsui Bussan Kankyo Foundation (R09 -B022 to MY).

\section{Appendix A. Supplementary data}

Supplementary data related to this article can be found at http:// dx.doi.org/10.1016/j.quaint.2014.12.009.

\section{Appendices}




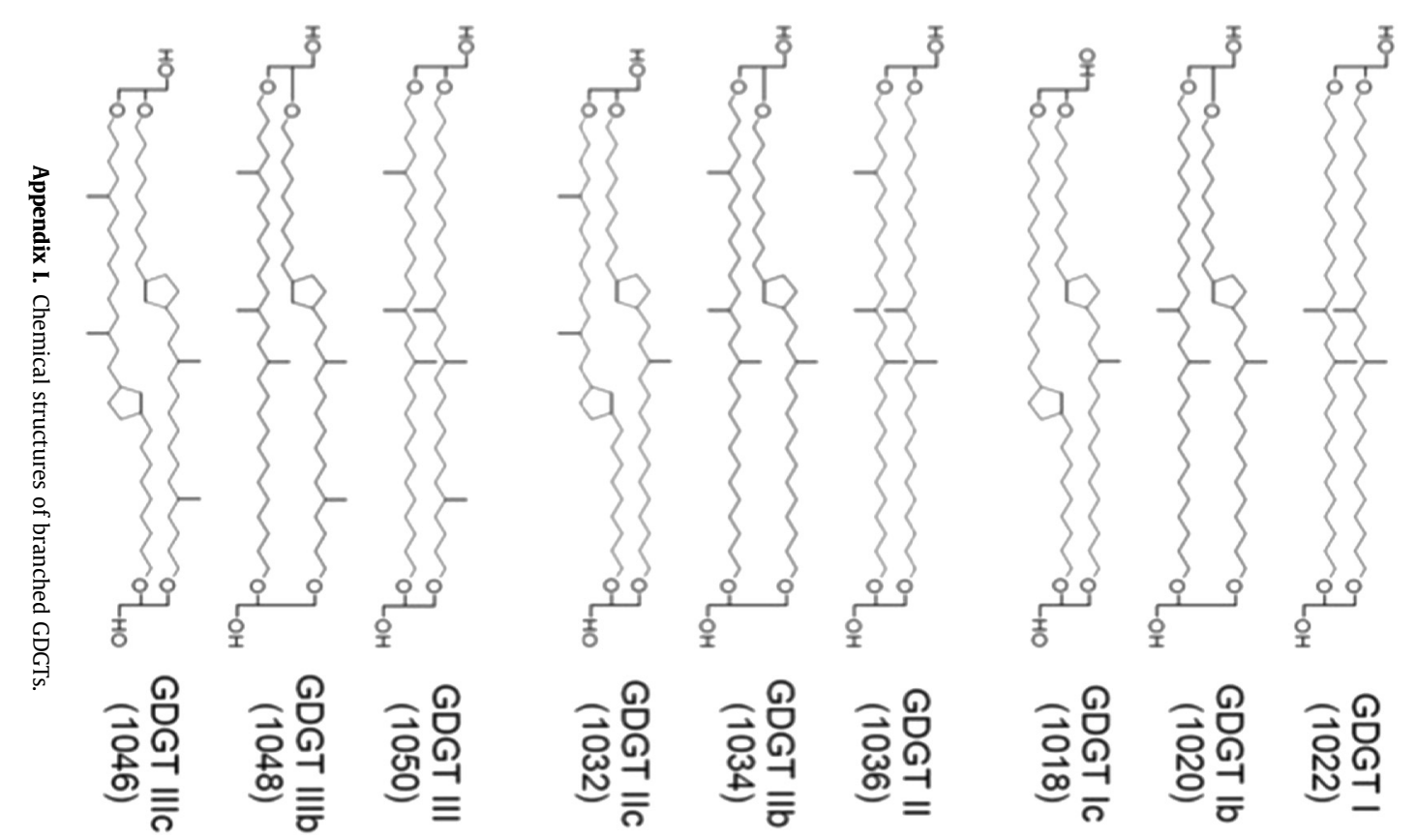

Appendix II

Data for surface samples.

\begin{tabular}{|c|c|c|c|c|c|c|c|c|c|c|c|c|c|c|}
\hline \multirow[t]{2}{*}{ Site } & \multirow[t]{2}{*}{ Measured pH } & \multirow[t]{2}{*}{ Climatological MAAT $\left({ }^{\circ} \mathrm{C}\right)$} & \multicolumn{2}{|c|}{ Concentration $(\mu \mathrm{g} / \mathrm{g})$} & \multirow[t]{2}{*}{ BIT } & \multirow[t]{2}{*}{$\mathrm{TEX}_{86}$} & \multirow[t]{2}{*}{ MI } & \multirow[t]{2}{*}{$\mathrm{MBT}^{\prime}$} & \multirow[t]{2}{*}{ CBT } & \multicolumn{2}{|c|}{ CBT-based pH } & \multicolumn{2}{|c|}{ MBT'/CBT-based MAAT } & \multirow[t]{2}{*}{$\mathrm{A} / \mathrm{N}$} \\
\hline & & & isoGDGTs & brGDGTs & & & & & & Global calib & Regional calib & Global calib & Regional calib & \\
\hline 1 & 3.2 & 10.3 & 0.880 & 3.338 & 0.91 & 0.70 & 0.48 & 0.787 & 1.510 & 4.9 & 4.2 & 16.7 & 12.0 & $\mathrm{~N}$ \\
\hline 2 & 3.9 & 10.3 & 0.092 & 1.954 & 0.99 & 0.66 & 0.55 & 0.841 & 1.715 & 4.5 & 3.7 & 17.2 & 12.5 & A \\
\hline 3 & 3.9 & 10.5 & 0.357 & 2.330 & 0.94 & 0.68 & 0.45 & 0.830 & 1.048 & 5.8 & 5.3 & 20.6 & 16.5 & $\mathrm{~N}$ \\
\hline 4 & 4.4 & 10.7 & 0.069 & 1.271 & 0.99 & 0.63 & 0.69 & 0.855 & 1.131 & 5.7 & 5.1 & 20.9 & 16.8 & A \\
\hline 6 & 4.0 & 10.9 & 0.753 & 3.872 & 0.93 & 0.70 & 0.48 & 0.795 & 1.090 & 5.8 & 5.2 & 19.3 & 15.1 & A \\
\hline 7 & 5.2 & 11.3 & 0.412 & 1.827 & 0.99 & 0.63 & 0.92 & 0.792 & 0.855 & 6.2 & 5.8 & 20.5 & 16.5 & A \\
\hline 8 & 5.2 & 11.8 & 0.069 & 1.893 & 0.99 & 0.54 & 0.73 & 0.773 & 0.936 & 6.1 & 5.6 & 19.5 & 15.3 & $\mathrm{~N}$ \\
\hline 9 & 3.6 & 12.0 & 0.100 & 1.400 & 0.97 & 0.68 & 0.48 & 0.827 & 1.229 & 5.5 & 4.9 & 19.5 & 15.2 & A \\
\hline 10 & 4.5 & 11.7 & 0.024 & 0.502 & 0.98 & 0.64 & 0.49 & 0.805 & 1.468 & 5.0 & 4.3 & 17.5 & 12.9 & $\mathrm{~N}$ \\
\hline 11 & 5.1 & 12.1 & 1.132 & 6.111 & 0.94 & 0.72 & 0.56 & 0.751 & 0.905 & 6.1 & 5.7 & 18.9 & 14.8 & A \\
\hline 12 & 4.2 & 12.2 & 0.120 & 0.609 & 0.94 & 0.68 & 0.54 & 0.825 & 1.316 & 5.3 & 4.7 & 18.9 & 14.6 & $\mathrm{~N}$ \\
\hline 13 & 4.5 & 12.4 & 0.319 & 9.202 & 1.00 & 0.66 & 0.79 & 0.802 & 1.320 & 5.3 & 4.7 & 18.2 & 13.8 & A \\
\hline 14 & 4.7 & 12.5 & 0.065 & 2.154 & 0.99 & 0.58 & 0.57 & 0.802 & 1.362 & 5.2 & 4.5 & 17.9 & 13.5 & A \\
\hline 15 & 5.6 & 12.5 & 0.329 & 3.303 & 0.99 & 0.60 & 0.81 & 0.692 & 0.822 & 6.3 & 5.9 & 17.6 & 13.3 & A \\
\hline 17 & 5.2 & 12.6 & 0.541 & 1.606 & 0.90 & 0.62 & 0.53 & 0.705 & 0.892 & 6.1 & 5.7 & 17.6 & 13.3 & A \\
\hline 18 & 5.8 & 12.7 & 0.660 & 3.589 & 0.90 & 0.68 & 0.35 & 0.627 & 0.670 & 6.6 & 6.3 & 16.4 & 12.1 & A \\
\hline 20 & 5.4 & 12.9 & 1.959 & 7.092 & 0.95 & 0.65 & 0.72 & 0.811 & 1.074 & 5.8 & 5.3 & 19.9 & 15.7 & A \\
\hline 21 & 4.9 & 13.4 & 0.565 & 1.962 & 0.91 & 0.67 & 0.49 & 0.728 & 0.910 & 6.1 & 5.7 & 18.2 & 14.0 & A \\
\hline 16 & 6.3 & 14.6 & 0.154 & 1.539 & 0.92 & 0.53 & 0.23 & 0.632 & 0.543 & 6.8 & 6.6 & 17.3 & 13.1 & A \\
\hline 22 & 4.4 & 14.0 & 0.005 & 0.198 & 0.99 & 0.63 & 0.63 & 0.883 & 1.563 & 4.8 & 4.0 & 19.3 & 14.9 & $\mathrm{~N}$ \\
\hline 23 & 3.9 & 14.6 & 0.000 & 0.567 & 1.00 & ND & ND & 0.956 & 1.924 & 4.1 & 3.1 & 19.5 & 15.1 & $\mathrm{~N}$ \\
\hline 24 & 4.3 & 14.4 & 0.005 & 1.253 & 1.00 & ND & ND & 0.799 & 0.904 & 6.1 & 5.7 & 20.5 & 16.4 & $\mathrm{~N}$ \\
\hline 25 & 6.1 & 15.0 & 0.058 & 1.416 & 0.98 & 0.61 & 0.20 & 0.688 & 0.489 & 6.9 & 6.7 & 19.4 & 15.4 & A \\
\hline 26 & 5.5 & 14.9 & 0.151 & 1.425 & 0.94 & 0.64 & 0.21 & 0.668 & 0.585 & 6.7 & 6.5 & 18.2 & 14.1 & A \\
\hline 27 & 5.0 & 14.9 & 0.089 & 1.394 & 0.95 & 0.83 & 0.21 & 0.700 & 0.706 & 6.5 & 6.2 & 18.5 & 14.3 & A \\
\hline
\end{tabular}

$\mathrm{ND}=$ not determined, $\mathrm{A} / \mathrm{N}=$ All of the MBT'-related seven branched GDGTs were quantified or not. 
Appendix III

Data for subsurface samples from sites 2, 20, 22, and 25 .

\begin{tabular}{|c|c|c|c|c|c|c|c|c|c|c|c|c|c|c|c|c|c|}
\hline \multirow[t]{2}{*}{ Site no. } & \multirow[t]{2}{*}{ Altitude (m) } & \multirow{2}{*}{$\begin{array}{l}\text { Depth }(\mathrm{cm}) \\
\text { top }\end{array}$} & \multirow{2}{*}{$\begin{array}{l}\text { Depth }(\mathrm{cm}) \\
\text { Bottom }\end{array}$} & \multirow[t]{2}{*}{ Measured $\mathrm{pH}$} & \multirow{2}{*}{$\begin{array}{l}\text { Claimatological } \\
\text { MAAT }\left({ }^{\circ} \mathrm{C}\right)\end{array}$} & \multicolumn{2}{|l|}{ Concentration } & \multirow[t]{2}{*}{ BIT } & \multirow[t]{2}{*}{$\mathrm{TEX}_{86}$} & \multirow[t]{2}{*}{ MI } & \multirow[t]{2}{*}{$\mathrm{MBT}^{\prime}$} & \multirow[t]{2}{*}{ CBT } & \multicolumn{2}{|c|}{ CBT-based pH } & \multicolumn{2}{|c|}{ MBT'/CBT-based MAAT } & \multirow[t]{2}{*}{$\mathrm{A} / \mathrm{N}$} \\
\hline & & & & & & $(\mu \mathrm{g} / \mathrm{g})$ isoGDGT & brGDGTs & & & & & & Global calib & Regional calib & Global calib & Regional calib & \\
\hline 2 & 1019 & 0 & 5 & 3.9 & 10.3 & 0.092 & 1.954 & 0.99 & 0.66 & 0.55 & 0.841 & 1.715 & 4.5 & 3.7 & 17.2 & 12.5 & A \\
\hline 2 & 1019 & 5 & 10 & 4.5 & 10.3 & 0.148 & 1.305 & 0.98 & 0.65 & 0.71 & 0.855 & 1.436 & 5.1 & 4.4 & 19.2 & 14.8 & A \\
\hline 2 & 1019 & 10 & 15 & 4.5 & 10.3 & 2.022 & 8.591 & 0.96 & 0.66 & 0.70 & 0.833 & 1.294 & 5.4 & 4.7 & 19.3 & 15.0 & A \\
\hline 2 & 1019 & 15 & 20 & 4.8 & 10.3 & 0.873 & 2.847 & 0.97 & 0.71 & 0.83 & 0.832 & 1.225 & 5.5 & 4.9 & 19.7 & 15.4 & A \\
\hline 2 & 1019 & 20 & 25 & 4.9 & 10.3 & 1.079 & 2.079 & 0.97 & 0.73 & 0.92 & 0.836 & 1.130 & 5.7 & 5.1 & 20.3 & 16.2 & A \\
\hline 2 & 1019 & 25 & 30 & 4.8 & 10.3 & 0.905 & 1.544 & 0.96 & 0.73 & 0.89 & 0.827 & 1.088 & 5.8 & 5.2 & 20.3 & 16.2 & A \\
\hline 20 & 535 & 0 & 5 & 5.4 & 12.9 & 1.959 & 7.092 & 0.95 & 0.65 & 0.72 & 0.811 & 1.074 & 5.8 & 5.3 & 19.9 & 15.7 & A \\
\hline 20 & 535 & 5 & 10 & 5.2 & 12.9 & 2.458 & 6.462 & 0.94 & 0.62 & 0.75 & 0.827 & 1.120 & 5.7 & 5.2 & 20.1 & 16.0 & A \\
\hline 20 & 535 & 10 & 15 & 5.2 & 12.9 & 1.623 & 5.006 & 0.96 & 0.63 & 0.77 & 0.846 & 1.173 & 5.6 & 5.0 & 20.4 & 16.3 & A \\
\hline 20 & 535 & 15 & 20 & 5.3 & 12.9 & 3.034 & 5.806 & 0.95 & 0.62 & 0.83 & 0.856 & 1.068 & 5.8 & 5.3 & 21.3 & 17.3 & A \\
\hline 20 & 535 & 20 & 25 & 4.9 & 12.9 & 0.822 & 1.445 & 0.94 & 0.65 & 0.81 & 0.827 & 0.950 & 6.0 & 5.6 & 21.1 & 17.1 & A \\
\hline 20 & 535 & 25 & 30 & 5.4 & 12.9 & 0.582 & 1.098 & 0.95 & 0.63 & 0.85 & 0.837 & 1.003 & 5.9 & 5.4 & 21.1 & 17.1 & A \\
\hline 22 & 341 & 0 & 5 & 4.4 & 14.0 & 0.005 & 0.198 & 0.99 & ND & ND & 0.883 & 1.563 & 4.8 & 4.0 & 19.3 & 14.9 & $\mathrm{~N}$ \\
\hline 22 & 341 & 5 & 10 & 4.8 & 14.0 & 0.028 & 0.168 & 0.99 & 0.60 & 0.94 & 0.823 & 1.185 & 5.6 & 5.0 & 19.6 & 15.4 & $\mathrm{~N}$ \\
\hline 22 & 341 & 10 & 15 & 5.2 & 14.0 & 0.278 & 0.491 & 0.99 & 0.64 & 0.96 & 0.820 & 1.052 & 5.8 & 5.3 & 20.3 & 16.2 & $\mathrm{~N}$ \\
\hline 22 & 341 & 15 & 20 & 5.4 & 14.0 & 0.336 & 0.270 & 0.98 & 0.68 & 0.98 & 0.822 & 0.908 & 6.1 & 5.7 & 21.1 & 17.2 & A \\
\hline 22 & 341 & 20 & 25 & 5.1 & 14.0 & 0.548 & 0.375 & 0.98 & 0.69 & 0.97 & 0.813 & 0.879 & 6.2 & 5.8 & 21.0 & 17.1 & A \\
\hline 22 & 341 & 25 & 30 & 5.4 & 14.0 & 0.370 & 0.620 & 0.99 & 0.67 & 0.98 & 0.839 & 1.099 & 5.7 & 5.2 & 20.6 & 16.5 & A \\
\hline 25 & 163 & 0 & 5 & 6.1 & 15.0 & 0.058 & 1.416 & 0.98 & 0.61 & 0.20 & 0.688 & 0.489 & 6.9 & 6.7 & 19.4 & 15.4 & A \\
\hline 25 & 163 & 5 & 10 & 6.1 & 15.0 & 0.050 & 1.174 & 0.98 & 0.67 & 0.24 & 0.726 & 0.555 & 6.8 & 6.6 & 20.2 & 16.2 & A \\
\hline 25 & 163 & 10 & 15 & 6.1 & 15.0 & 0.020 & 0.460 & 0.98 & 0.51 & 0.38 & 0.738 & 0.571 & 6.8 & 6.5 & 20.5 & 16.5 & A \\
\hline 25 & 163 & 15 & 20 & 6.1 & 15.0 & 0.009 & 0.214 & 0.99 & 0.41 & 0.54 & 0.761 & 0.598 & 6.7 & 6.5 & 21.0 & 17.1 & A \\
\hline 25 & 163 & 20 & 25 & 6.2 & 15.0 & 0.009 & 0.196 & 0.99 & 0.51 & 0.63 & 0.807 & 0.658 & 6.6 & 6.3 & 22.1 & 18.3 & $\mathrm{~N}$ \\
\hline 25 & 163 & 25 & 30 & 6.1 & 15.0 & 0.012 & 0.148 & 0.98 & 0.46 & 0.60 & 0.775 & 0.587 & 6.7 & 6.5 & 21.5 & 17.7 & A \\
\hline
\end{tabular}

$\mathrm{ND}=$ not determined, $\mathrm{A} / \mathrm{N}=$ All of the MBT'-related seven branched GDGTs were quantified or not. 
Appendix IV

Data for the paleosol sequence at Site 5.

\begin{tabular}{|c|c|c|c|c|c|c|c|c|c|c|c|c|c|c|}
\hline \multirow[t]{2}{*}{ Depth (cm) } & \multirow[t]{2}{*}{ Age (ka) } & \multirow{2}{*}{$\begin{array}{l}\text { Measured } \\
\text { soil pH }\end{array}$} & \multicolumn{2}{|l|}{ Concentration } & \multirow[t]{2}{*}{ BIT } & \multirow[t]{2}{*}{$\mathrm{TEX}_{86}$} & \multirow[t]{2}{*}{ MI } & \multirow[t]{2}{*}{$\mathrm{MBT}^{\prime}$} & \multirow[t]{2}{*}{ CBT } & \multicolumn{2}{|c|}{ CBT-based $\mathrm{pH}$} & \multicolumn{2}{|c|}{ MBT'/CBT-based MAAT } & \multirow[t]{2}{*}{$\mathrm{A} / \mathrm{N}$} \\
\hline & & & $(\mu \mathrm{g} / \mathrm{g})$ isoGDGT & brGDGTs & & & & & & Global calib & Regional calib & Global calib & Regional calib & \\
\hline 5 & 0.79 & 4.8 & 0.042 & 0.232 & 1.00 & 0.58 & 1.00 & 0.838 & 0.906 & 6.1 & 5.7 & 21.6 & 17.7 & A \\
\hline 16 & 1.05 & 5.1 & 0.491 & 0.731 & 0.99 & 0.67 & 0.97 & 0.849 & 0.945 & 6.0 & 5.6 & 21.8 & 17.8 & A \\
\hline 27 & 1.31 & 5.1 & 0.170 & 0.247 & 0.99 & 0.72 & 0.97 & 0.836 & 1.009 & 5.9 & 5.4 & 21.0 & 17.0 & A \\
\hline 38 & 1.57 & 5.1 & 0.291 & 0.592 & 0.99 & 0.70 & 0.94 & 0.845 & 0.951 & 6.0 & 5.6 & 21.6 & 17.7 & A \\
\hline 49 & 1.83 & 5.1 & 0.379 & 0.461 & 0.99 & 0.69 & 0.98 & 0.849 & 0.952 & 6.0 & 5.6 & 21.7 & 17.8 & A \\
\hline 60 & 2.24 & 5.3 & 0.214 & 0.334 & 0.99 & 0.66 & 0.97 & 0.878 & 0.970 & 6.0 & 5.5 & 22.5 & 18.7 & A \\
\hline 71 & 3.99 & 5.6 & 0.124 & 0.310 & 0.99 & 0.66 & 0.97 & 0.866 & 0.867 & 6.2 & 5.8 & 22.7 & 19.0 & A \\
\hline 82 & 4.34 & 5.6 & 0.049 & 0.134 & 0.97 & 0.65 & 0.83 & 0.867 & 0.888 & 6.2 & 5.7 & 22.6 & 18.8 & A \\
\hline 93 & 4.61 & 5.3 & 0.077 & 0.536 & 1.00 & 0.61 & 0.95 & 0.899 & 1.050 & 5.8 & 5.3 & 22.7 & 18.9 & A \\
\hline 103 & 5.17 & 5.4 & 0.050 & 0.368 & 1.00 & 0.59 & 0.99 & 0.897 & 0.999 & 5.9 & 5.5 & 23.0 & 19.2 & A \\
\hline 114 & 5.71 & 5.6 & 0.041 & 0.180 & 1.00 & 0.58 & 1.00 & 0.908 & 0.938 & 6.1 & 5.6 & 23.6 & 19.9 & A \\
\hline 125 & 5.72 & 5.9 & 0.041 & 0.064 & 0.95 & 0.70 & 0.83 & 0.857 & 0.735 & 6.5 & 6.1 & 23.2 & 19.5 & A \\
\hline 136 & 5.72 & 5.9 & 0.038 & 0.324 & 1.00 & 0.62 & 1.00 & 0.878 & 0.825 & 6.3 & 5.9 & 23.4 & 19.7 & A \\
\hline 147 & 6.80 & 5.4 & 0.009 & 0.357 & 1.00 & ND & ND & 0.920 & 1.042 & 5.8 & 5.3 & 23.4 & 19.6 & A \\
\hline 158 & 7.23 & 5.7 & 0.014 & 0.091 & 0.99 & 0.48 & 0.88 & 0.907 & 1.034 & 5.9 & 5.4 & 23.1 & 19.3 & A \\
\hline 169 & 7.64 & 5.0 & 0.099 & 0.554 & 1.00 & 0.54 & 0.97 & 0.901 & 1.154 & 5.6 & 5.1 & 22.2 & 18.3 & A \\
\hline 180 & 8.33 & 5.4 & 0.098 & 0.530 & 1.00 & 0.54 & 1.00 & 0.879 & 1.047 & 5.8 & 5.3 & 22.1 & 18.2 & A \\
\hline 191 & 9.02 & 5.3 & 0.144 & 1.081 & 0.97 & 0.66 & 0.32 & 0.872 & 1.067 & 5.8 & 5.3 & 21.8 & 17.8 & A \\
\hline 202 & 9.71 & 5.3 & 0.068 & 0.545 & 1.00 & 0.52 & 1.00 & 0.868 & 0.974 & 6.0 & 5.5 & 22.2 & 18.3 & A \\
\hline 212 & 10.40 & 5.4 & 0.096 & 0.350 & 1.00 & 0.59 & 1.00 & 0.853 & 0.971 & 6.0 & 5.5 & 21.8 & 17.8 & A \\
\hline 223 & 11.09 & 5.7 & 0.091 & 0.243 & 0.99 & 0.65 & 0.97 & 0.846 & 0.948 & 6.0 & 5.6 & 21.6 & 17.7 & A \\
\hline 234 & 11.78 & 5.7 & 0.094 & 0.125 & 1.00 & ND & ND & 0.862 & 1.039 & 5.9 & 5.4 & 21.6 & 17.7 & $\mathrm{~N}$ \\
\hline 245 & 12.47 & 5.8 & 0.039 & 0.068 & 1.00 & 0.56 & 1.00 & 0.856 & 0.993 & 5.9 & 5.5 & 21.7 & 17.8 & $\mathrm{~N}$ \\
\hline 256 & 13.16 & 5.7 & 0.009 & 0.020 & 1.00 & 0.54 & 1.00 & 0.867 & 1.146 & 5.6 & 5.1 & 21.2 & 17.2 & $\mathrm{~N}$ \\
\hline 267 & 13.85 & 5.6 & 0.009 & 0.019 & 1.00 & ND & ND & 0.834 & 1.333 & 5.3 & 4.6 & 19.1 & 14.8 & $\mathrm{~N}$ \\
\hline 278 & 14.54 & 5.8 & 0.008 & 0.019 & 0.97 & 0.61 & 0.92 & 0.872 & 1.386 & 5.2 & 4.5 & 20.0 & 15.7 & $\mathrm{~N}$ \\
\hline 289 & 15.23 & 5.6 & 0.003 & 0.026 & 0.91 & 0.64 & 0.86 & 0.876 & 1.314 & 5.3 & 4.7 & 20.5 & 16.4 & $\mathrm{~N}$ \\
\hline
\end{tabular}

$\mathrm{ND}=$ not determined, $\mathrm{A} / \mathrm{N}=$ All of the MBT'-related seven branched GDGTs were quantified or not.

\section{References}

Ajioka, T., Yamamoto, M., Murase, J., 2014a. Branched and isoprenoid glycerol dialkyl glycerol tetraethers in soils and lake/river sediments in Lake Biwa basin and implications for MBT/CBT proxies. Organic Geochemistry 73, 70-82.

Ajioka, T., Yamamoto, M., Takemura, K., Hayashida, A., Kitagawa, H., 2014b. Water $\mathrm{pH}$ and temperature in Lake Biwa from $\mathrm{MBT}^{\prime} / \mathrm{CBT}$ indices during the last 282 000 years. Climate of the Past 10, 1843-1855.

Hopmans, E.C.,Schouten, S., Pancost, R., van der Meer, M.T.J. Sinninghe Damsté, J.S., 2000 Analysis of intact tetraether lipids in archaeal cell material and sediments by high performance liquid chromatography/atmospheric pressure chemical ionization mass spectrometry. Rapid Communications in Mass Spectrometry 14, 585-589.

Hopmans, E.C., Weijers, J.W.H., Schefuß, E., Herfort, L., Sinninghe Damsté, J.S., Schouten, S., 2004. A novel proxy for terrestrial organic matter in sediments based on branched and isoprenoid tetraether lipids. Earth and Planetary Science Letters 24, 107-116.

Huguet, C., Hopmans, E.C., Febo-Ayala, W., Thompson, D.H., Sinninghe Damsté, J.S., Schouten, S., 2006. An improved method to determine the absolute abundance of glycerol dibiphytanyl glycerol tetraether lipids. Organic Geochemistry 37, 1036-1041.

Huguet, A., Gocke, M., Derenne, S., Fosse, C., Wiesenberg, G.L.B., 2013. Root-associated branched tetraether source microorganisms may reduce estimated paleotemperatures in subsoil. Chemical Geology 356, 1-10.

Igarashi, Y., Oba, T., 2006. Fluctuations of monsoons and insolation in the northwest Pacific during the last $144 \mathrm{kyr}$ from a high-resolution pollen analysis of the IMAGES core MD01-2421. Quaternary Science Reviews 25, 1447-1459.

Isono, D. Yamamoto, M., Irino, T., Oba, T., Murayama, M., Nakamura, T. Kawahata, K., 2009. The 1,500-year climate oscillation in the mid-latitude North Pacific during the Holocene. Geology 37, 591-594.

Kamata, H., Kobayashi, T., 1997. The eruptive rate and history of Kuju volcano in Japan during the past 15,000 years. Journal of Volcanology and Geothermal Research 76, 163-171.

Kubota, Y., Kimoto, K., Tada, R., Oda, H., Yokoyama, Y., Matsuzaki, H., 2010. Variations of East Asian summer monsoon since the last deglaciation based on $\mathrm{Mg} / \mathrm{Ca}$ and oxygen isotope of planktic foraminifera in the northern East China Sea. Paleoceanography 25. PA4205.

Kuroda, T. Hatanaka, K. 1979. Palynological study of the late Quaternary in the coastal plain along Hakata Bay, in Fukuoka City, northern Kyushu, Japan. Daiyonkikenkyuu (The Quaternary Research) 18, 53-68.

Nishihara, M., Morii, H., Koga, Y., 1987. Structure determination of a quartet of novel tetraether lipids from Methanobacterium thermoautotrophicum. The Journal of Biochemistry 101, 1007-1015.

Okuno, M., Goshim, N., Fujisawa, Y., Nakamura, T., Kobayashi, T., 2004. ${ }^{14} \mathrm{C}$ chronology of humic soil on the northern foot of Yufu volcano, SW Japan. Summaries of Researches Using AMS at Nagoya University XV, 35-40 (in Japanese with English abstract).
Patwardhan, A.P. Thompson, D.H. 1999. Efficient synthesis of 40- and 48membered tetraether macrocyclic bisphosphocholines. Organic Letters 1, 241-243.

Peterse, F., Prins, M.A., Beets, C.J. Troelstra, S.R., Zheng, H., Gu, Z., Schouten, S. Sinninghe Damsté, J.S., 2011. Decoupled warming and monsoon precipitation in East Asia over the last deglaciation. Earth and Planetary Science Letters 301 256-264.

Peterse, F., Meer, J.V.D., Schouten, S., Weijers, J.W.H., Fierer, N., Jackson, R.B., Kim, J.H., Sinninghe Damsté, J.S., 2012. Revised calibration of the MBT-CBT paleotemperature proxy based on branched tetraether membrane lipids in surface soils. Geochimica et Cosmochimica Acta 96, 215-229.

Schouten, S., Hopmans, E.C., Pancost, R.D., Sinninghe Damsté, J.S., 2000. Widespread occurrence of structurally diverse tetraether membrane lipids: evidence for the ubiquitous presence of low-temperature relatives of hyperthermophiles. Proceedings of the National Academy of Science, USA 97, 14421-14426.

Schouten, S., Hopmans, E.C., Schefuß, E., Sinninghe Damsté, J.S., 2002. Distributiona variations in marine crenarchaeotal membrane lipids: a new tool for reconstructing ancient sea water temperatures? Earth and Planetary Science Letters 204, 265-274.

Schouten, S., Huguet, C., Hopmans, E.C., Kienhuis, M.V.M., Sinninghe Damsté, J.S. 2007. Analytical methodology for TEX86 paleothermometry by high performance liquid chromatography/atmospheric pressure chemical ionization-mass spectrometry. Analytical Chemistry 79, 2940-2944.

Schouten, S., Hopmans, E.C., Sinninghe Damsté, J.S., 2013. The organic geochemistry of glycerol dialkyl glycerol tetraether lipids: a review. Organic Geochemistry 54 $19-61$.

Schouten, S., Hopmans, E.C., Rosell-Mele, A., Pearson, A., Adam, P., Bauersachs, T., Bard, E., Bernasconi, S.M., Bianchi, T.S., Brocks, J.J., Carlson, L.T., Castaneda, I.S. Derenne, S., Do grul Selver, A., Dutta, K., Eglinton, T., Fosse, C., Galy, V., Grice, K. Hinrichs, K.-U., Huang, Y., Huguet, A., Huguet, C., Hurley, S., Ingalls, A., Jia, G. Kondo, M., Krishnan, S., Lincoln, S., Lipp, J., Mangelsdorf, K., Menot, G., Mets, A., Mollenhauer, G., Ohkouchi, N., Ossebaar, J., Pagani, M., Pancost, R.D. Pearson, E.J., Peterse, F., Reichart, G.-J., Schaeffer, P., Schmitt, G., Schwark, L., Shah, S.R., Smith, R.W., Smittenberg, R.H., Summons, R.E., Takano, Y., Talbot, H.M., Taylor, K.W.R., Tarozo, R., Uchida, M., van Dongen, B.E., Van Mooy, B.A.S., Wang, J., Warren, C., Weijers, J.W.H., Werne, J.P., Woltering, M. Xie, S., Yamamoto, M., Yang, H., Zhang, C.L., Zhang, Y., Zhao, M., Jaap, S., Sinninghe Damste, J.S., 2014. An interlaboratory study of TEX T6 $_{86}$ and BIT analysis of sediments, extracts, and standard mixtures. Geochemistry, Geophysics, Geosystems 14, 5263-5285.

Sinninghe Damsté, J.S., Hopmans, E.C., Pancost, R.D., Schouten, S., Geenevasen, J.A.J., 2000. Newly discovered non-isoprenoid dialkyl diglycerol tetraether lipids in sediments. Journal of the Chemical Society, Chemical Communications 23, 1683-1684.

Sinninghe Damsté, J.S., Rijpstra, W.I.C., Hopmans, E.C., Weijers, J.W.H., Foesel, B.U. Overmann, J., Dedysh, S.N., 2011. 13,16-Dimethyl octacosanedioic acid (iso- 
diabolic acid): a common membrane-spanning lipid of Acidobacteria subdivisions 1 and 3. Applied and Environmental Microbiology 77, 4147-4154.

Wang, B., Clemens, S.C., Liu, P., 2003. Contrasting the Indian and East Asian monsoons: implications on geologic timescales. Marine Geology 201, 5-21.

Weijers, J.W.H., Schouten, S., Geenevasen, J.A.J., David, O.R.P., Coleman, J., Pancost, R.D., Sinninghe Damsté, J.S., 2006a. Membrane lipids of mesophilic anaerobic bacteria thriving in peats have typical archaeal traits. Environmental Microbiology 8, 648-657.

Weijers, J.W.H., Schouten, S., Spaargaren, O.C., Sinninghe Damsté, J.S., 2006b. Occurrence and distribution of tetraether membrane in soils: implications for the use of the BIT index and the TEX86 SST proxy. Organic Geochemistry 37 1680-1693.

Weijers, J.W.H., Schefuß, E., Schouten, S., Sinninghe Damsté, J.S., 2007a. Coupled thermal and hydrological evolution of tropical Africa over the last deglaciation. Science 315, 1701-1704.

Weijers, J.W.H. Schouten, S., van Den Donker, J.C., Hopmans, E.C., Sinninghe Damsté, J.S., 2007b. Environmental controls on bacterial tetraether membrane lipid distribution in soils. Geochimica et Cosmochimica Acta 71, 703-713.
Yamamoto, M., Suemune, R., Oba, T., 2005. Equatorward shift of the subarctic boundary in the northwestern Pacific during the last deglaciation. Geophysical Research Letters 32, L05609.

Yamamoto, M., 2009. Response of mid-latitude North Pacific surface temperatures to orbital forcing and linkage to the East Asian summer monsoon and tropical ocean-atmosphere interactions. Journal of Quaternary Science 24, 836-847.

Yamamoto, M., Polyak, L., 2009. Changes in terrestrial organic matter input to the Mendeleev Ridge, western Arctic Ocean, during the Late Quaternary. Global and Planetary Change 68, 30-37.

Yamanoi, T., 1996. Geological investigation on the origin of the black soil, distributed in Japan. Journal of Geological Society of Japan 102, 526-544.

Yoshino, M.M., 1965. Four stages of the rainy season in early summer over East Asia (part I). Journal of the Meteorological Society of Japan 43, 231-245.

Zech, R., Gao, L., Tarozo, R., Huang, Y., 2012. Branched glycerol dialkyl glycerol tetraethers in Pleistocene loess-paleosol sequences: three case studies. Organic Geochemistry 53, 38-44.

Zhang, Y.G., Zhang, C.L., Liu, X.L., Li, L., Hinrichs, K.U., Noakes, J.E., 2011. Methane Index: a tetraether archaeal lipid biomarker indicator for detecting the instability of marine gas hydrates. Earth and Planetary Science Letters 307, 525-534. 